\title{
THE NEW UNDERSTATEMENT PENALTY REGIME: A SHARP 'SWORD'?
}

\author{
Linda van Zyl \\ University of Stellenbosch \\ Ivschalk@sun.ac.za
}

Received: March 2014

Accepted: June 2014

\begin{abstract}
The objective of this article was to form an opinion on the sharpness of the 'sword' of the new mandatory understatement penalty regime of the Tax Administration Act 28 of 2011 (as amended). Based on a review of the new bona fide inadvertent error exclusion and the burden of proof, it was found that it is imperative that comprehensive guidelines be issued expediently in order to prevent inconsistent application by South African Revenue Service (SARS) officials as well as to clarify the alleged automatic penalty position. The conclusion reached is that this sword is very sharp indeed based on its mandatory nature, the effect of the application of the highest penalty percentage and the current lack of guidance from SARS, especially regarding the practical application of the new bona fide inadvertent error exclusion.
\end{abstract}

Keywords

Bona fide inadvertent error, Burden of proof, Understatement penalty, Substantial understatement, Reasonable care, Reasonable grounds, Gross negligence, Intentional tax evasion.

Prof $L$ van $Z y l$ is an associate professor in the School of Accountancy, Stellenbosch University, South Africa. 


\section{INTRODUCTION}

Penalties have always been a part of the South African tax system. The Short Guide to the Tax Administration Act, 2013 (2013:73) (Short Guide) states that the principal goal of sanctions (penalties) is based on a simple premise, namely that the threat of punishment (imposition and effective collection of monetary administrative sanctions) deters unwanted behaviour (noncompliance and tax evasion). The new penalty regime introduced in the Tax Administration Act 28 of 2011 (the TAA) is divided into three categories, namely administrative penalties, understatement penalties and criminal offences and is aimed at ensuring consistent treatment of taxpayers in comparable circumstances (Short Guide, 2013:78)).

The old open-ended discretion of the South African Revenue Service (SARS), in terms of section 76 of the Income Tax Act 58 of 1962 (the ITA), to remit additional tax of up to $200 \%$ in the event of default or omission by the taxpayer, was replaced by a limited discretionary power to remit the new mandatory understatement penalty contained in sections 221 to 224 of the TAA. Section 222(1) of the TAA imposes the understatement penalty in the case of an 'understatement' (as defined in section 221 of the TAA) by a taxpayer unless the understatement results from a bona fide inadvertent error (this exception was introduced in the Tax Administration Laws Amendment Act 39 of 2013 and applies from 10 ctober 2012).

SARS has no discretion to impose such a penalty or to impose a penalty at a lower percentage. Section 222(1) of the TAA directs that a taxpayer 'must' pay the penalty in the event of an 'understatement' (unless the bona fide inadvertent error exception applies). It is submitted that a strict application of section 222(1) effectively means that SARS must impose an understatement penalty if there is an 'understatement' as defined provided that SARS has ruled out a bona fide inadvertent error.

In light of the mandatory nature of the understatement penalty it is therefore of the utmost importance to understand what the bona fide inadvertent error exception means and to know who bears the burden to proof that this exception does or does not apply. Neither the TAA nor the Short Guide offers any guidance in this regard. It is submitted that the lack of comprehensive guidelines regarding the process to identify and rule out a bona fide inadvertent error may prove to be to the detriment of taxpayers due to possible inconsistent application and even possible abuse of this new exception.

'Understatement' is defined in section 221 of the TAA as any prejudice to SARS or the fiscus as a result of one of four forms of conduct by the taxpayer:

- A default in rendering a return, or

- An omission from a return, or

- An incorrect statement in a return, or

- The failure to pay the correct amount of tax if no return is required.

It is submitted that the word 'any' makes this penalty excessively wide since it effectively means that, in light of its mandatory nature, any amount of a shortfall due to an understatement (however small) will lead to this penalty being imposed (provided a bona fide inadvertent error was ruled out). It is questioned whether this was the intention of the legislator in light of the illustration in the Short Guide (2013:73-74) describing the understatement penalty as 'serious 
non-compliance' that results in an understatement of tax due linked to the culpability of the types of behaviour in TABLE I (TABLE 1 is discussed in section 4 below).

SARS will be prejudiced if there is a shortfall (as explained in section 222(3) of the TAA) as a result of the taxpayer's conduct. SARS explains that, in simple terms, the shortfall is the difference between the correct amount of tax that should have been reported and the amount that was reported by the taxpayer (Short Guide (2013:78)). The prejudice to SARS therefore is the shortfall in tax paid due to the understatement.

Arendse and Williams (2013:31) identify various uncertainties in the application of the new understatement penalty regime and state that it is apparent that the new penalties create significant uncertainty, are harsher than the current additional tax regime in practice, and are likely to operate to the detriment of most taxpayers. They also anticipate that the material reduction in the discretion of SARS to remit penalties will have a net material adverse impact on taxpayers going forward (2013:33).

\section{RESEARCH OBJECTIVE AND VALUE OF RESEARCH}

The objective of this article is to form an opinion on the sharpness of the 'sword' of the new mandatory understatement penalty regime. The achievement of this objective necessitates the answering of the following research questions:

- What does the phrase 'bona fide inadvertent error' mean?

- Who bears the burden of proof and what is the effect thereof on the order of the steps needed before an understatement penalty can be imposed by SARS?

- What factors must SARS have regard to when determining whether the conduct of the taxpayer was due to a bona fide inadvertent error or not?

- How must SARS apply TABLE 1 in section 223 of the TAA?

Specific regard is given to the tax administration law of Australia because the TAA was drafted taking, inter alia, the Australian tax administration law into account, and the wording in the TAA concerning penalties is very similar to that of Australia. Previous research on the question of how the taxpayer can manage his exposure to the understatement penalty is also taken into account in forming an opinion on the sharpness of the sword of the new mandatory understatement penalty regime.

In light of the relatively short lapse of time since the TAA and the amendments thereto were promulgated, very little academic literature on the topic currently exists. No South African case law has to date ruled on any of the research questions above. The contribution of this article is to provide such academic literature with clarity and guidance relating to the research questions.

\section{MEANING OF THE PHRASE ‘BONA FIDE INADVERTENT ERROR’}

\subsection{Introduction}

Section 25(2) of the TAA requires that a return must contain the information prescribed by a tax Act or the Commissioner and must be a full and true return. Many taxpayers complete and 
submit their income tax returns without any assistance, since there is no minimum skills requirement in this regard. Even an exceptionally intelligent man like Albert Einstein, however, found this a daunting task and, when asked about filling out his income tax form in 1944, stated: 'This is a question too difficult for a mathematician. It should be asked of a philosopher'. Making bona fide errors in completing a tax return would therefore seem quite human in spite of the requirements in section 25(2) of the TAA.

The crucial importance of a taxpayer's obligation to submit honest and accurate tax returns was also underlined by the Courts in many tax cases concerning the 'old' understatement penalty in terms of section 76 of the ITA. The case of CIR v Di Ciccio [1985] 47 SATC 199 at 205 confirmed that it was not essential for an 'intent to evade' to be present before the section 76 additional tax could be levied; an omission of a required amount or an incorrect statement was enough to trigger the discretionary imposition thereof. It is submitted that, even though the imposition of the section 76 penalty was not discretionary per se, the court used the words 'discretional imposition' in light of the previous wide discretion SARS had to remit or reduce a penalty so imposed. The fact that a bona fide inadvertent error must now first be ruled out before an understatement penalty can be imposed therefore, at first glance, seems to be a welcome and positive step, especially in light of the current limited power of SARS to remit the penalty.

The effect of the different burdens of proof on the sequence of the steps needed to be taken by SARS before an understatement penalty can be imposed must first be clarified. It is submitted that, if comprehensive guidelines regarding the process to identify and rule out a bona fide inadvertent error are not issued and applied consistently and properly by SARS officials, the bona fide inadvertent error-exclusion might prove to be of little value.

\subsection{The burden of proof}

A taxpayer can (still) request reasons for an assessment in terms of section 107A of the ITA, and, if not satisfied, the taxpayer can object to an assessment within a specified period. SARS can then request information from the taxpayer and if the objection is disallowed by SARS, a taxpayer may appeal against that. It is only at the point of appeal that the issue of the burden of proof arises (therefore after an assessment was issued and the objection process is completed).

The list of items (in terms of the now-repealed section 82 of the ITA) in respect of which the burden of proof rests on a taxpayer was expanded by section 102(1) of the TAA. It was held in Ochberg $v$ CIR [1931] 5 SATC 93 that the effect of section 82 of the ITA is that an amount received by a taxpayer on which an assessment has been made is taxable unless the taxpayer shows that it is not income. Although the words creating this effect no longer appear in the corresponding provision of the TAA, namely section 102(1), De Koker and Williams (2014:18.146) doubt whether the omission has any significance. The burden of proof is clear. De Beer J, in Commissioner for Inland Revenue $v$ Goodrick [1942] 12 SATC 279 held that what is required from a taxpayer to discharge the onus in the now-repealed section 82 of the ITA is affirmative evidence which satisfies the court. It is submitted that this ruling will apply equally to the corresponding provision of the TAA, namely section 102(1).

The burden to prove that the taxpayer has made a bona fide inadvertent error in a return is, however, not one of the listed items, and it is submitted that it is also not implied in section 102(1) of the TAA that the taxpayer bears this burden. If a taxpayer does not bear the burden to 
prove that he has made a bona fide inadvertent error in a return resulting in an understatement as defined, who does?

In a welcome new clause, section 102(2) of the TAA places the burden to prove the facts upon which the imposition of the understatement penalty is based upon SARS. No procedural guidelines are provided for in the TAA in relation to the manner in which SARS should discharge this onus (Arendse \& Williams, 2013:31). De Koker and Williams (2014:18.146) correctly state that the party bearing the onus of proof (SARS) must establish the facts from which the desired inference can and should properly be drawn, and that in judicial proceedings those facts must be established by way of admissible evidence.

It is submitted that the section 102(2)-burden of proof, inter alia, includes that SARS must, on a balance of probabilities, prove the correctness of its decision to impose the understatement penalty. It is further submitted that sections 102 (2) and 222(1) of the TAA read together place an additional 'implied burden of proof' on SARS regarding a bona fide inadvertent error. This is because an understatement penalty can be imposed by SARS only as a result of something other than a bona fide inadvertent error. The Commissioner of SARS must therefore, after establishing that there is an 'understatement' as defined, but before imposing an understatement penalty, apply his mind to the specific facts and circumstances of the matter in order to rule out, on a balance of probabilities, that the conduct of the taxpayer was a bona fide inadvertent error. What SARS must do in order to discharge this 'implied burden of proof' is an open question and issuing guidelines in this regard is imperative.

From a practical perspective, it is submitted that a taxpayer should make submissions to SARS during the course of an audit (or in the process of supplying information and evidence after a request from SARS during the objection process), to enable SARS to reach the correct conclusion regarding the bona fide inadvertent error. The only defence a taxpayer has against a decision by SARS in this regard is to lodge an objection against the imposition of an understatement penalty (in terms of section 224 of the TAA).

\subsection{The alleged automatic default penalty position}

Kriel, tax director at Grant Thornton, Cape Town (2012) submits that, whilst it is still early days, it appears that SARS has taken a default position that every additional assessment they issue must be punished with a penalty and that they automatically impose a penalty under the behaviour type in item (ii) of TABLE I ('reasonable care not taken in completing the return') in respect of all additional assessments they issue. He states that it appears as if it is SARS's view that all additional assessments that they issue must carry an understatement penalty, and to complicate matters further, taxpayers are not always provided with reasons for the SARS decision to impose the understatement penalty. Kriel also states that it is questionable whether it was the intention of the legislature to punish taxpayers for all mistakes they make and that one can only hope that SARS will take a more lenient approach in applying the understatement penalty provisions than what appears to be the case currently.

The mandatory nature of the understatement penalty and the effect of the words 'any prejudice' must, however, be remembered. The critical unanswered question regarding such alleged automatic default penalty position is whether SARS had properly applied its mind in order to rule out a bona fide inadvertent error, as well as to rule out the other four types of behaviour in 
TABLE l, before imposing such an automatic default penalty when an additional assessment is issued.

Applying an automatic default penalty position is contentious and must therefore be investigated, clarified and rectified (if needed). Imposing an automatic default penalty without following all the steps listed above would cause the new understatement penalty regime in the TAA to be a sharper sword than intended by the legislature. It will also leave SARS vulnerable for an attack, using the objection and appeal process, on the basis that they have unfairly or incorrectly applied the provisions of the TAA.

\subsection{The meaning of the phrase 'bona fide inadvertent error' and how is it determined}

Since neither the TAA nor the Short Guide offers guidance in this regard, the ordinary meaning of the words must be established. 'Bona fide' is a Latin phrase that means 'in good faith', and thus sincere or genuine (The Free Dictionary by Farlex, 2014) and according to the Oxford Reference Dictionary (2014) it means 'real' or 'genuine'. The opposite of good faith is bad faith (mala fide), and this may involve intentional deceit.

'Inadvertent' is not a tax-defined term. Dictionaries contain definitions such as 'not focusing the mind on a matter: inattentive' and 'unintentional' (Merriam Webster Online Dictionary and Thesaurus: 2014), as well as 'marked by unintentional lack of care' and 'characterized by a lack of attention' (The Free Dictionary by Farlex, 2014).

An error is 'an act involving an unintentional deviation from truth or accuracy; it is 'something that is not correct' (Merriam Webster Online Dictionary and Thesaurus: 2014). A 'bona fide error' is an error that was unintentional; an 'honest error' (Investopedia Dictionary, 2014).

From the above it is therefore clear that SARS cannot impose an understatement penalty if the shortfall results from an honest, unintentional or inattentive act or violation by a sincere taxpayer completing a tax return which leads to something that is not correct in the return. This confirms that SARS must first critically apply its mind to rule out a bona fide inadvertent error and underlines the need for comprehensive guidance in this regard.

The Draft Memorandum on the Objects of the Tax Administration Laws Amendment Bill, 2013 (2013:par. 2.62) (Draft Memorandum) stated that, in determining if the 'understatement' results from a bona fide inadvertent error, a SARS official will generally have regard to the circumstances in which the error was made as well as other factors, for example:

In the context of factual errors

- If the standard of care taken by the taxpayer in completing the return is commensurate with the taxpayer's knowledge, education, experience and skill and the care a reasonable person in the same circumstances would have exercised.

- The size or quantum, nature and frequency of the error.

- Whether a similar error was made in a return submitted during the preceding years.

- In the case of an arithmetical error, whether the taxpayer had procedures in place to detect arithmetical errors.

In the case of a legal interpretive error, whether 
- The relevant provision of the tax Act is generally regarded as complex.

- The taxpayer took steps to understand it, including following available explanatory material or making reasonable enquiries.

- The taxpayer relied on information that, although incorrect or misleading, came from reputable sources and a reasonable person in the same circumstances would be likely to find the relevant information complex.

Parliament's Standing Committee on Finance has heard submissions on the Draft Tax Administration Law Amendment Bill, 2013, and it was suggested that the phrase 'bona fide inadvertent error' should be defined (Du Preez, 2013). The Memorandum on the Objects of the Tax Administration Laws Amendment Bill, 2013 (2013:40) (the final Memorandum) however, stated that due to the broad range of possible errors, the proposal to define the phrase has the potential to inadvertently exclude deserving cases and include undeserving cases. It also stated that SARS will develop guidance in this regard for the use of taxpayers and SARS officials.

The factors listed in the Draft Memorandum were excluded from the final Memorandum and it remains to be seen what guidelines and criteria SARS will issue in this regard. The importance of issuing comprehensive guidelines expediently is stressed once again, especially in light of the alleged specific automatic default penalty applied by SARS.

\section{THE APPLICATION OF THE TABLE IN SECTION 223 OF THE TAA}

The following understatement penalty percentage table is contained in section 223 of the TAA:

TABLE 1: Understatement penalty percentage (section 223 of the TAA)

\begin{tabular}{|c|c|c|c|c|c|}
\hline 1 & 2 & 3 & 4 & 5 & 6 \\
\hline Item & Behaviour types & $\begin{array}{l}\text { Standard } \\
\text { case }\end{array}$ & $\begin{array}{c}\text { If obstructive, or } \\
\text { if it is a 'repeat } \\
\text { case' }\end{array}$ & $\begin{array}{l}\text { Voluntary disclosure } \\
\text { after notification of } \\
\text { audit or investigation }\end{array}$ & $\begin{array}{l}\text { Voluntary disclosure } \\
\text { before notification of } \\
\text { audit or investigation }\end{array}$ \\
\hline (i) & $\begin{array}{l}\text { 'Substantial } \\
\text { understatement' }\end{array}$ & $10 \%$ & $20 \%$ & $5 \%$ & $0 \%$ \\
\hline (ii) & $\begin{array}{l}\text { Reasonable care } \\
\text { not taken in } \\
\text { completing return }\end{array}$ & $25 \%$ & $50 \%$ & $15 \%$ & $0 \%$ \\
\hline (iii) & $\begin{array}{l}\text { No reasonable } \\
\text { grounds for 'tax } \\
\text { position' taken }\end{array}$ & $50 \%$ & $75 \%$ & $25 \%$ & $0 \%$ \\
\hline (iv) & Gross negligence & $100 \%$ & $125 \%$ & $50 \%$ & $5 \%$ \\
\hline (v) & $\begin{array}{l}\text { Intentional tax } \\
\text { evasion }\end{array}$ & $150 \%$ & $200 \%$ & $75 \%$ & $10 \%$ \\
\hline
\end{tabular}

Source: Section 223 of the TAA

The understatement penalty is determined by locating each case within TABLE 1 contained in section 223 of the TAA. Apart from the understatement penalty, an additional assessment will 
also be issued by SARS at any time SARS is satisfied that an assessment does not reflect the correct application of a tax Act to the prejudice of SARS or the fiscus (section 92 of the TAA).

TABLE 1 is applied with reference to the five types of behaviour listed from (i) tot ( $v$ ) and the conduct of the taxpayer listed in columns 3 to 6 . The behaviour types are listed in order of increasing severity as far as the penalty rate and the degree of culpability involved is concerned. Although the 'least culpable' behaviour type listed first is that of a substantial understatement, the Short Guide (2013:79) makes it clear that an understatement penalty based on this behaviour type will only be triggered if no other behaviour type (listed in (ii) to (v)) defines the facts of the case. Similarly, the 'standard case'-conduct in column 3 will only be applicable if the case is not defined by any of the other three conducts listed in columns 4 to 6 .

This is to give effect to section 222(2) of the TAA which states that the understatement penalty is the amount resulting from applying the highest applicable understatement penalty percentage in the table to each shortfall in tax paid determined in relation to each understatement (being any prejudice to SARS as a result of one of the four conducts listed in the definition of understatement) in a return. In other words, if a taxpayer's behaviour involves both that no reasonable grounds exist for a tax position taken (behaviour type (iii) in TABLE 1) and gross negligence (behaviour type (iv) in TABLE 1), behaviour type (iv) will apply. It is therefore clear that SARS must consider all the types of behaviour and all the possible conducts before imposing an understatement penalty. Merely applying the alleged 'reasonable care not taken in completing the return' behaviour type as an automatic default penalty could therefore indicate that SARS has not properly applied its mind.

It is submitted that section 222(2) of the TAA is a very sharp point of the sword of the understatement penalty that will prove to deter intentional culpable behaviours by taxpayers. The section concurrently places a huge responsibility on SARS officials to properly apply their minds in order to ensure that they can discharge their burden of proof. It is suggested that a comprehensive standardised list of factors to be taken into account, and questions to be asked by SARS officials before imposing an understatement penalty, will prove to assist its officials to minimize the influence of bias or subjectivity when applying TABLE 1 .

It is clear that the sequence of steps SARS must take before imposing a specific percentage understatement penalty (and issuing an additional assessment) is therefore:

- issue an assessment

- establish a shortfall due to an understatement as defined,

- rule out a bona fide inadvertent error,

- consider all the types of behaviour and identify the correct applicable type,

- consider all the possible conducts to determine if one applies.

Khaki (2012:7) explains that the types of behaviour (apart from the 'substantial understatement') have not been defined in the TAA, and that penalties raised in respect of those types of behaviour are very subjective, since it depends on the person who is assessing the return. It is submitted that the incidence of such subjectivity is aggravated by the lack of comprehensive guidelines and that more detailed and specific guidelines will have to be issued by SARS to ensure that all of its officers consistently apply the same principles in determining an understatement penalty. The behaviour types as indicated in TABLE 1 are now discussed in order 
to identify possible factors to be included in such a list and to consider previous research on the question of how the taxpayer can manage his exposure to the understatement penalty.

\subsection{Substantial understatement}

A substantial understatement is defined in section 221 of the TAA as a case where the prejudice to SARS or the fiscus exceeds the greater of five percent of the amount of 'tax' properly chargeable or refundable under a tax Act for the relevant period, or Rl 000000 . The word 'tax' in this context excludes interest and penalties. The words 'considerable' and 'significant' are synonyms for the word 'substantial' (Thesaurus Dictionary: 2014). To be classified as 'substantial' the shortfall in tax paid must therefore exceed the greater of the two limits as stated, and since this involves mere mathematical calculations, it is submitted that it will be quite easy for SARS to discharge the burden of proof in this regard.

A natural person with a shortfall of R1 000000 in tax paid would most definitely be taxed at the highest percentage of 40 percent, and this would imply that the amount of income not declared would be R2 500000 (R1 000000 divided by $40 \%$ ). This is indeed a significant or substantial understatement of income. In a standard case, an understatement penalty of $10 \%$ will be imposed in respect of such a substantial understatement (provided that none of the other types of behaviour listed in (ii) to (v) is proved). It is, however, submitted that it is questionable that a non-declaration of income amounting to R2 500000 (in the example) would not fall foul of one of the other four types of behaviour.

The importance of the causal relationship between culpability and the percentage of the penalty is clear if one realizes that a natural person not taking reasonable care in completing a return and consequently omitting a much smaller amount of income than R2 500000 will be penalized at a higher percentage than that of a substantial understatement. For example, if a natural person with a taxable income of R800 000 does not declare an amount of income of R500 000 due to not taking reasonable care in completing his return, the tax properly chargeable on R1 300000 will be R445 972 (R195 212 plus (40\% x R626 900)) and the shortfall will be R200 000 (R500 $000 \times 40 \%$ ). Five percent of R445 972 (the tax properly chargeable) is R22 298.60. This would therefore not be a substantial understatement because the shortfall in tax paid (R200 000) does not exceed the greater of R22 298.60 (five percent of the tax properly chargeable) and R1 000000 . However, due to not taking reasonable care, the understatement penalty in such a standard case will be $25 \%$ (and therefore $15 \%$ higher than the standard case of a substantial understatement).

It seems harsh that a person causing a lesser harm to SARS in Rand value (R200 000 in the example) is penalized at a higher percentage than a person causing SARS greater harm (R1 000000 in the example). Substantial understatements are, however, determined by mathematical calculations, while 'reasonable care not taken' indicates a lack of taxpayer behaviour. This confirms that the new understatement penalty regime predominantly targets more serious non-compliance and stresses the importance of taxpayer behaviour as well as the need for proper guidelines applied consistently by SARS officials.

Van der Zwan (2013:8-13) states that since the behaviour type of a substantial understatement is based on the quantity of the understatement, as opposed to an actual behaviour (as in the case of behaviour types in (ii) - (v)), there would have been very little a taxpayer could do to manage the risk of a penalty if it was not for section 223(3) of the TAA. Section 223(3) gives SARS a limited power to remit an understatement penalty if SARS is satisfied that the taxpayer 
made full disclosure of the arrangement that prejudiced SARS by the date the return was due and the taxpayer was in possession of an opinion by an independent tax practitioner meeting three specific requirements listed in section $223(3)(\mathrm{b})(\mathrm{i})$ - (iii). One of these requirements is that the said opinion must be issued by no later than the date that the relevant return was due. Van der Zwan (2013:8-13) correctly argues that 'although this provision clearly provides taxpayers with a procedural mechanism that it can implement to ensure that it is not exposed to an understatement penalty, the time limitation of 'by the date the return was due' is critical and might prove impractical to meet'. This impractical time constraint should be reconsidered by SARS.

\subsection{Reasonable care not taken in completing return}

The Short Guide (2013:80) gives limited guidelines as to what is expected from a taxpayer in this regard. It merely states that 'reasonable care means that a taxpayer is required to take the degree of care that a reasonable, ordinary person in the circumstances of the taxpayer would take to fulfil his or her tax obligations. The reasonable care standard does not mean perfection, but refers to the effort required commensurate with the reasonable person in the taxpayer's circumstances'.

Cliffe Dekker Hofmeyr (2013) correctly points out that the guideline in the Short Guide merely restates the well-known 'man on the Clapham omnibus' test. The man on the Clapham omnibus is a hypothetical reasonable person, used by the courts in English law where it is necessary to decide whether a party has acted as a reasonable person would, for example, in a civil action for negligence. The man on the Clapham omnibus is a reasonably educated and intelligent but nondescript person, against whom the defendant's conduct can be measured (Wikipedia: 2014).

Since the drafting of the TAA was informed taking into account, inter alia, Australian administrative law, it is submitted that it is fitting to take their guidance into account. It was held in the Australian case of Federal Commissioner of Taxation v Traviati [2012] 205 FCR 136 that reasonable care is an objective test linked to a reasonable person but the particular (and subjective) circumstances relevant to the taxpayer are to be considered in applying the test. Popplewell of the law firm Burges Salmon, UK (2013) also explains that (similarly), in the United Kingdom (UK), different standards of care will apply in different situations, since HM Revenue and Customs ('HMRC') states that 'reasonable care cannot be identified without consideration of the particular person's abilities and circumstances'. It is therefore clear that the aforementioned guidelines in the Short Guide are in agreement with administrative law in both Australia and the UK.

The Australian Tax Office (ATO) gives further guidance on the meaning of 'reasonable care' in Miscellaneous Tax Ruling (MT 2008/1):

- Taking 'reasonable care' in the context of making a statement to the Commissioner means giving appropriately serious attention to complying with the obligations imposed under a taxation law (2008:par. 27).

- The reasonable care test requires an entity to take the same care in fulfilling their tax obligations that could be expected of a reasonable ordinary person in their position. This means that even though the standard of care is measured objectively it takes into account the taxpayer's circumstances (2008:par. 28). 
- The objective test does not depend on the actual intentions of the taxpayer; it is not a question of whether the taxpayer actually foresaw the impact of the act or failure to act, but whether a reasonable person in all the circumstances would have foreseen it (2008:par. 34).

- The reasonable care test has a clear link to the principles applied in the law of negligence, and 'reasonable' does not connote the highest possible level of care or perfection. Perfection or the use of increased knowledge or experience embraced in hindsight after the event should form no part of the components of what is reasonable in all the circumstances. That matter must be judged in prospect and not in retrospect (2008:par. 35).

- The appropriate standard of care required in making a statement is not immutable but takes account of the particular characteristics of the person concerned. Because there is no 'one size fits all' standard, the standard of care that is appropriate in a particular case necessarily takes account of:

- personal circumstances (such as age, health, and background);

- level of knowledge, education, experience and skill; and

- understanding of the tax laws (2008:par. 45).

From the above it therefore seems that SARS will have to prove, objectively and on a balance of probabilities, that the taxpayer did not act as a reasonable man in completing his return by taking into account, inter alia, the subjective personal circumstances of the taxpayer, his abilities, characteristics and knowledge of tax laws. It is submitted that more guidance is needed to ensure the objectivity of all SARS officials. It is further submitted that if SARS applies the alleged 'no reasonable care taken' type of behaviour as an automatic default position without properly applying its mind, SARS will contravene a taxpayer's right to just administrative action in terms of section 33 of the Constitution of the Republic of South Africa, 1996.

Van der Zwan (2013:8-13) submits that it should be possible for a taxpayer to mitigate the risk of a penalty resulting from not taking reasonable care in completing a return to a large extent by implementing certain adequate and appropriate controls and procedures over the processes that generate the information used in the return and to complete the tax return, and by being able to demonstrate that. It is submitted that the application of the 'no reasonable care taken' type of behaviour as an automatic default penalty position could, however, deprive a taxpayer of aforementioned chance to manage his risk under item (ii).

\subsection{No reasonable grounds for tax position taken}

'Tax position' is defined in section 221 of the TAA and means an assumption underlying one or more aspects of a tax return, including whether or not

(a) an amount, transaction, event or item is taxable;

(b) an amount or item is deductible or may be set-off;

(c) a lower rate of tax than the maximum applicable to that class of taxpayer, transaction, event or item applies; or

(d) an amount qualifies as a reduction of tax payable. 
The Short Guide (2013:80) states that

- Where an underpayment of tax occurs due to a taxpayer's interpretation of the application of a tax Act, an understatement penalty is payable if the taxpayer does not have a reasonably arguable position.

- A taxpayer's interpretation of the application of the law is reasonably arguable if, having regard to the relevant authorities, for example an income tax law, a court decision or a general ruling, it would be concluded that what is being argued by the taxpayer is at least as likely as not correct.

- The purpose is not to levy a penalty when SARS disagrees with a position adopted by a taxpayer, but to attach a penalty where a taxpayer assumes a position unreasonably. As there is an inherent risk in assuming a tax position, taxpayers are expected to adopt a sensible approach in the process of adopting a tax position and to also have considered the integrity of the tax position taken.

The Australian equivalent for this type of behaviour is 'reasonably arguable position'. The AT0 in MT 2008/1 (2008:par. 39-40) explains that the reasonably arguable position test focuses solely on the merits of the position taken. The reasonably arguable position test is a purely objective standard involving an analysis of the law and application of the law to the relevant facts and personal circumstances are not taken into account.

Australian case law held in Federal Commissioner of Taxation v R \& D Holdings Pty Ltd [2007] 160 $F C R 248$ that, on a balance, the taxpayer's argument must be one which can be objectively said to be one that, while wrong, could be argued on rational grounds to be right. It was also concluded in Re Traviati and Federal Commissioner of Taxation [2011] 83 ATR 981 that the reasonably arguable position test is a higher standard to meet than the reasonable care standard, and if a taxpayer has adopted such a reasonably arguable position the reasonable care standard should be regarded as having been met.

Although the similarities between the Short Guide and the MT 2008/1 are clear and the Australian equivalent of 'reasonable arguable position' was even specifically used in the Short Guide (instead of 'reasonable grounds'), it remains to be seen whether the guidelines developed by SARS or South African case law will follow the Australian law and case law.

Van der Zwan (2013:8-13) is correct in arguing that a taxpayer will be in a position where he has no reasonable grounds for a tax position taken if he is not able to reasonably argue the assumptions made or views taken in respect of any aspect of the mentioned aspects affecting his tax obligation or position. In this regard, Van der Zwan (2013) states that written views, including tax opinions, as to how an assumption or view was arrived at should go a long way in ensuring that the taxpayer can provide reasonable grounds for a tax position taken. Van der Zwan also opines that the involvement of a tax specialist may enhance the position of the taxpayer as to the reasonability of these grounds, especially where the views or assumptions deal with a more complex matter.

It must, however, be remembered that the burden is on SARS to prove, it seems, objectively and without taking the personal circumstances of the taxpayer into account, that the taxpayer did not have a reasonable or rational argument regarding the interpretation or application of a tax Act. This may seem to be an easy task, but it remains to be seen what SARS will have to do in order to (in effect) disprove that what is being argued by the taxpayer is at least as likely as not correct. 


\title{
4.4 Gross negligence
}

Innes CJ, in Jameson's Minors v CSAR (1908 TS 586) explained the term 'negligence' as follows:

\begin{abstract}
The term negligence as used in our courts, simply means a failure to exercise that degree of diligence which the law requires under the circumstances of each case ... Whether the person whose conduct is under investigation is a specialist or an ordinary person, the fact remains that the diligence required of him is what reasonable specialists or reasonable men would exercise under similar circumstances.
\end{abstract}

The word 'gross', however, qualifies the word 'negligence' in the TAA, and it was held in Transnet Ltd t/a Portnet $v$ The Owners of the MV "Stella Tingas" \& Another [2003] I All SA 286 (SCA) that 'gross negligence' involves the extreme departure from the standard of a reasonable person which departure must demonstrate complete obtuseness of mind or total failure to take care.

The Short Guide (2013:80) explains that 'gross negligence' essentially means doing or not doing something in a way that, given all the circumstances, suggests or implies complete or a high level of disregard for the consequences. It further states that the test for gross negligence is objective and is based on what a reasonable person would foresee as being conduct which creates a high risk of a tax shortfall occurring. Taking the above definition of negligence into account, it is submitted that the 'reasonable person' referred to in this regard is a reasonable person in the position of the taxpayer. The risk of inconsistent application by SARS officials due to a lack of comprehensive guidelines exists and should be addressed expediently, especially in light of the high penalty percentage for this type of behaviour.

The Short Guide (2013) also distinguishes between 'gross negligence' and 'tax evasion' by stating that gross negligence involves recklessness but, unlike evasion, does not require an element of mens rea, meaning wrongful intent or 'guilty mind', or intent to breach a tax obligation. The word 'recklessness' is defined in the Legal Dictionary (2014) as 'Rashness; heedlessness; wanton conduct. The state of mind accompanying an act that either pays no regard to its probably or possibly injurious consequences, or which, though foreseeing such consequences, persists in spite of such knowledge. Recklessness transcends ordinary negligence.' It therefore seems that the word 'recklessness' can be used to indicate the 'gross' nature of the negligence.

It is submitted that the word 'recklessness' in the Short Guide (2013:102) was possibly taken from the ATO in MT 2008/1, which also refers to 'recklessness' by stating that recklessness assumes that the relevant behaviour shows disregard of or indifference to a risk that is foreseeable by a reasonable person. It was held that the degree of the risk and the gravity of consequences needed to be weighed in deciding whether the conduct is reckless and that each case has to be viewed on its own particular facts and not by reference to any formula (Shawinigan Ltd v Volkins \& Co Ltd 1 [1961] W.L.R. 1206 at 1214).

Van der Zwan (2013:8-15) clearly states that a person merely failing to take the degree of care that people usually undertake in similar circumstances may be negligent, but not grossly negligent. He submitted that it would be unlikely that a taxpayer would be regarded as being grossly negligent when he or she implements processes with built-in controls that take into account the tax consequences of certain transactions or events. He explains that 'this may be particularly relevant in the case of regular day-to-day activities; for example, a process checking that captured invoices complies with the requirements of the VAT Act to deduct input tax. For less frequent or once-off events, such as structuring of deals or transactions, the risk of being grossly negligent towards the tax consequences should to a large extent be manageable by 
documenting reasons or arguments for taking positions and showing that those tax consequences have been considered (i.e. not complete lack of intellect in relation to the tax implications of the event).'

\subsection{Intentional tax evasion}

In terms of the Short Guide (2013:81) the most severe penalty is reserved for cases where a taxpayer has acted with the intention to evade tax. It explains:

- To evade tax includes actions that are intended to reduce or extinguish the amount that should be paid, or which inflate the amount of a refund that is correctly refundable to the taxpayer. Intentional tax evasion can exist where a taxpayer makes a false statement in a return, and even where a person does not file a return.

- The most important factor is that the taxpayer must have acted with intent to evade tax. Intention is a wilful act, that exists when a person's conduct is meant to disobey or wholly disregard a known legal obligation, and knowledge of illegality is crucial. Whether SARS acts on or accepts a false declaration is irrelevant. If SARS does not accept the declaration, but audits the taxpayer and determines the correct tax position the original intent to evade tax is not excused. Intention may, at times, be difficult to distinguish from an act that is grossly negligent.

- Since the application of tax law to a particular taxpayer may be complex, it may be that a genuine misunderstanding of the practical application of a taxing provision does not indicate intentional tax evasion. If the taxing provision is uncertain, for instance if there are conflicting judgments on the issue, and the taxpayer applies a reasonable interpretation, it is doubtful that intent to evade could be established and that the more appropriate behavioural category would be whether the taxpayer had taken a tax position on unreasonable grounds or, at worse, that the taxpayer has been grossly negligent. This is an area that is also influenced by the nature of the actions that underlie an understatement and the circumstances of the taxpayer.

The influence of the Australian Administrative tax law is evident by MT 2008/1 pointing out that the adjective 'intentional' means that something more than reckless disregard of or indifference to a taxation law is required. It further states that intentional disregard means that there must be actual knowledge that the statement made is false, that the test for intentional disregard is purely subjective in nature and that the actual intention of the taxpayer is therefore crucial. It is submitted that a subjective test, where SARS, in a manner of speaking, will try to get into a particular person's mind in order to discharge its onus of proof, might prove to hold unique challenges. The court, in Weyers v Federal Commissioner of Taxation [2006] FCA 818; 2006 ATC 4523; (2006) 63 ATR 268, held that evidence of the taxpayer's intention should be found through direct evidence or by inferences from all the surrounding circumstances, including the taxpayer's conduct.

In terms of MT 2008/1, to establish intentional disregard the entity must understand the effect of the relevant legislation and how it operates in respect of the entity's affairs and make a deliberate choice to ignore the law. It further affirms that dishonesty is a requisite feature of behaviour that shows an intentional disregard for the operation of the law and points out the significant difference between this type of behaviour and behaviour that shows a want of reasonable care or recklessness where dishonesty is not an element. 
Van der Zwan (2013:8-15) states that intentional tax evasion will exist if taxpayers knowingly fail to comply with the requirements of a tax law in order not to pay the tax that they are legally obliged to pay. He distinguishes between intentional tax evasion and wrongfully applying complex legislation or intentionally doing tax planning to avoid tax in a manner which does not comply with the requirements of the relevant legislation. He submits that taxpayers can protect themselves from being classified under this category of behaviour by providing arguments and documenting proof of the fact that the taxpayer followed the requirements of the relevant tax legislation when he or she was busy tax planning, and that the planning was done within the confines of the law.

\section{CONCLUSION}

At first glance the exclusion of a bona fide inadvertent error by a taxpayer from the understatement penalty regime seems to accommodate taxpayers making human errors in returns. On a closer look, however, sorting out all the intricacies of the new legislation regarding the understatement penalty proves to be a task which will require much attention and detailed guidance from SARS.

The objective of this article was to form an opinion on the sharpness of the new 'sword' of the mandatory understatement penalty regime. It is submitted that this sword is very sharp indeed based on its mandatory nature, the effect of applying the highest penalty percentage in terms of section 222(2) of the TAA and the current lack of guidance from SARS, especially regarding the practical application of the new bona fide inadvertent error exclusion. Although Van der Zwan is correct about how a taxpayer can manage his exposure to this penalty, it is submitted that the combined influence of possible subjectivity and inconsistent application by SARS officials due to a lack of comprehensive guidelines, the impractical time constraint in section 223(3) of the TAA and the alleged specific automatic default penalty position might have an unintended negative impact on the extent to which a taxpayer can manage his exposure.

SARS may impose an understatement penalty only after ruling out a bona fide inadvertent error. In light of the mandatory nature of the understatement penalty it is therefore of the utmost importance to understand what the bona fide inadvertent error exception means and who bears the onus to prove that this exception does or does not apply. It was submitted that sections $102(2)$ and 222(1) of the TAA read together place an additional 'implied burden of proof' on SARS regarding a bona fide inadvertent error. The guidance regarding how a SARS official will determine whether an understatement results from a bona fide inadvertent error offered in the Draft Memorandum was, however, omitted from the Final Memorandum, leaving taxpayers and tax practitioners in the dark with a mere undertaking that SARS will develop guidelines in this regard. It is submitted that it is imperative that comprehensive guidelines regarding the process to identify and rule out a bona fide inadvertent error are issued by SARS expediently in order to prevent inconsistent application and even possible abuse of this new exception.

The alleged application of the 'reasonable care not taken' behaviour type as an automatic default penalty when SARS issue additional assessments is contentious and causes great concern. This should be investigated, clarified and rectified (if needed). Lacking comprehensive guidelines, the question of whether SARS has properly applied its mind in order to rule out a bona fide inadvertent error, as well as to rule out the other four types of behaviour outlined in TABLE 1 , before imposing such an automatic default penalty remains critically unanswered. It is submitted that if SARS applies the 'reasonable care not taken' behaviour type as an automatic 
default penalty position as alleged without first properly applying its mind in all regards, SARS will contravene a taxpayer's right to just administrative action in terms of section 33 of the Constitution of the Republic of South Africa, 1996.

The lack of comprehensive guidelines regarding the process to identify and rule out a bona fide inadvertent error may prove to be to the detriment of taxpayers due to possible inconsistent application and even possible abuse of this new exception. The suggestion is made that a complete standardized list of factors to be taken into account, and questions to be asked by SARS officials when applying TABLE 1 , must be issued by SARS in order to assist its officials to minimize the influence of bias or subjectivity and to ensure consistent application by, and the objectivity of, all SARS officials.

A lot of uncertainty still clouds the application of the new understatement penalty regime, and it is submitted that SARS honouring its undertaking to issue guidance will contribute positively to ensure that all of its officers consistently apply the same principles in ruling out a bona fide inadvertent error and in determining the correct understatement penalty in terms of TABLE 1 . It will also facilitate the aim of the new penalty regime as stated in the Short Guide (2013:78), namely ensuring consistent treatment of taxpayers in comparable circumstances.

\section{LIST OF REFERENCES}

Arendse, T. \& Williams, P. (2013). Beware of the new additional tax regime. TaxTalk, September/ October, pp. 30-33.

CIR v Di Ciccio [1985] 47 SATC 199.

Cliffe Dekker Hofmeyr. (2013). Understatement penalty: What does 'reasonable care not taken in completing return actually mean? [Online] Available:

http://www.polity.org.za/article/understatement-penalty-what-does-reasonable-care-nottaken-in-completing-return-actually-mean-2013-04-17. (Accessed 12 March 2014).

Commissioner for Inland Revenue v Goodrick [1942] 12 SATC 279.

De Koker, A. \& Williams, R.C. (2013). Silke on South African Income Tax. Johannesburg: LexisNexis Butterworths.

Du Preez, L. (2013). Move to scrap penalties for genuine tax errors. [Online] Available:

http://www.iol.co.za/business/personal-finance/tax/move-to-scrap-penalties-for-genuine-taxerrors-1.1577542. (Accessed 12 March 2014).

Einstein, A. [Online] Available: https://www.goodreads.com/quotes/tag/taxes?page=2. (Accessed 13 March 2014).

Federal Commissioner of Taxation v R \& D Holdings Pty Ltd [2007] 160 FCR 248.

Federal Commissioner of Taxation v Traviati [2012] 205 FCR 136.

HM Revenue and Customs. CH81120 - Penalties for Inaccuracies: Types of Inaccuracy: What is reasonable care. [Online] Available: http://www.hmrc.gov.uk/manuals/chmanual/ch81120.htm. (Accessed 12 March 2014). 
Investopedia Dictionary. [Online] Available: http://www.investopedia.com/terms/b/bona-fideerror.asp. (Accessed 12 March 2014).

Jameson's Minors v CSAR [1908] TS 586.

Khaki, S. (2012). The problem with SARS' new behavioural penalties. [Online] Available:

http://www.thesait.org.za/news/114806/The-Problem-With-SARS-New-Behavioural-Penalties.htm. (Accessed 12 March 2014).

Kriel, A. (2012). Tax administration Act - mistakes to cost taxpayers dearly. [Online] Available: http://www.gt.co.za/publications/2012/12/e-taxline-december-2012/. (Accessed 12 March 2013).

Legal dictionary. (2014). [Online] Available: http://legal-

dictionary.thefreedictionary.com/recklessness. (Accessed 12 March 2014).

Merriam Webster Online Dictionary and Thesaurus. [Online] Available: http://www.merriamwebster.com/dictionary/error. (Accessed 12 March 2014).

Merriam Webster Online Dictionary and Thesaurus. [Online] Available: http://www.merriamwebster.com/dictionary/inadvertent. (Accessed 12 March 2014).

Miscellaneous Tax Ruling MT 2008/1. [Online] Available:

http://law.ato.gov.au/atolaw/view.htm?DoclD=MXR/MT20081/NAT/ATO/00001. (Accessed 12 March 2014).

Ochberg v CIR [1931] 5 SATC 93

Oxford Reference Dictionary. [Online] Available:

http://www.oxforddictionaries.com/definition/english/bona-fide. (Accessed 12 March 2014).

Popplewell, N. [Online] Available: http://www.burges-

salmon.com/practices/tax/penalties_for_inaccuracies_failure_to_take_reasonable_care.aspx.

(Accessed 12 March 2014).

Re Traviati and Federal Commissioner of Taxation [2011] 83 ATR 981

South Africa. (1962). Income Tax Act No. 58 of 1962 (as amended). Pretoria: Government Printer.

South Africa. (2011). Tax Administration Act No. 28 of 2011. Pretoria: Government Printer.

South Africa. (2011). Tax Administration Amendment Act No. 39 of 2013. Pretoria: Government Printer.

SARS, vide South African Revenue Service.

South African Revenue Service. (2013). Short Guide to the Tax Administration Act, 2011 (Version 2). [Online] Available: http://www.sars.gov.za/Legal/TaxAdmin/Pages/Guides.aspx. (Accessed 12 March 2014).

South African Revenue Service. (1996). The Constitution of the Republic of South Africa, 1996.

[Online] Available: http://www.gov.za/documents/constitution/1996/a108-96.pdf. (Accessed 13 March 2014).

South African Revenue Service. (2013). The Draft Memorandum on the Objects of the Tax Administration Laws Amendment Bill, 2013. [Online] Available:

http://www.sars.gov.za/Legal/TaxAdmin/Pages/Guides.aspx. (Accessed 29 July 2013). 
South African Revenue Service. (2013). The Memorandum on the Objects of the Tax Administration Laws Amendment Bill, 2013. [Online] Available:

http://www.sars.gov.za/AllDocs/LegalDoclib/ExplMemo/LAPD-LPrep-EM-2013-

01\%20\%20Memorandum\%200bjects\%20Tax\%20Admin\%20 Laws\%20Amendment $\% 20$ Bill\%202013.pdf. (Accessed 12 March 2014).

Shawinigan Ltd v Volkins \& Co Ltd l [1961] W.L.R. 1206.

The Free Dictionary. (2014). [Online] Available: http://www.thefreedictionary.com/bona+fide. (Accessed 12 March 2014).

The Free Dictionary by Farlex. (2014). [Online] Available:

http://www.thefreedictionary.com/inadvertent. (Accessed 12 March 2014).

Thesaurus Dictionary. (2014). [Online] Available: http://thesaurus.com/browse/substantial. (Accessed 12 March 2014).

Transnet Ltd t/a Portnet v The Owners of the MV "Stella Tingas" \& Another [2003] I All SA 286 (SCA).

Van der Zwan, P. (2013). A taxpayer's right to manage exposure. [Online] Available:

http://www.thesait.org.za/news/116521/A-Taxpayers-Right-to-Manage-its-Exposure.htm. (Accessed 12 March 2014).

Weyers v. Federal Commissioner of Taxation [2006] FCA 818; 2006 ATC 4523; (2006) 63 ATR 268.

Wikipedia. (2014). [Online] Available:

http://en.wikipedia.org/wiki/The_man_on_the_Clapham_omnibus. (Accessed: 12 March 2014). 